\title{
Kegiatan Ekstrakurikuler Jarimatika dalam Membangun Keterampilan Berhitung
}

\author{
Anin Nafaikah ${ }^{1 *}$, Mudzanatun², Husni Wakhyudin ${ }^{3}$ \\ ${ }^{12}$ FIP Universitas PGRI Semarang, Indonesia \\ ${ }^{3}$ SDN Tlogosari Kulon 01 Semarang, Indonesia
}

\section{ARTICLEINFO}

Article history:

Received 18 May 2019

Received in revised form

30 June 2019

Accepted 15 July 2019

Available online 25 August 2019

\section{Kata Kunci:}

Ekstrakurikuler, Jarimatika,

Keterampilan Berhitung

Keywords:

Extracurricular, Jarimatika, Numeracy Skills

\begin{abstract}
A B S T R A K
Penelitian ini bertujuan untuk mengetahui kegiatan ekstrakurikuler jarimatika dalam membangun keterampilan berhitung siswa kelas IV semester II SDN Tlogosari Kulon 01 Semarang. Jenis penelitian ini menggunakan penelitian kualitatif deskriptif. Metode yang digunakan dalam penelitian ini yaitu wawancara,observasi, angket dan dokumentasi. Berdasarkan penelitian kegiatan ekstrakurikuler jarimatika dalam membangun keterampilan berhitung siswa kelas IV SDN Tlogosari Kulon 01 Semarang menyatakan bahwa Ekstrakurikuler jarimatika membuat siswa senang dan antusias dalam mengikutinya, sebanyak $84 \%$ siswa selalu mengikuti kegiatan ekstrakurikuler jarimatika, sebenyak $56 \%$ siswa sering menggunakan jari tanpa alat bantu sehingga membuat siswa mampu menyeimbangkan otak kanan dan otak kiri melalui berhitung cepat dan gerakan jari. siswa tidak hanya terampil berhitung saja tetapi siswa mampu menguasai berbagai mata pelajaran dikelas.
\end{abstract}

\section{A B S T R A C T}

This study aims to determine the fingerprint extracurricular activities in building the numeracy skills of fourth grade students in the second semester of SDN Tlogosari Kulon 01 Semarang. This type of research uses descriptive qualitative research. The methods used in this study are interviews, observation, questionnaires and documentation. Based on the research of Jarimatika extracurricular activities in building numeracy skills of fourth grade students of SDN Tlogosari Kulon 01 Semarang stated that Jarimatika extracurricular makes students happy and enthusiastic in following it, as much as $84 \%$ of students always participate in Jarimatika extracurricular activities, $56 \%$ of students often use fingers without tools so makes students able to balance the right brain and left brain through quick counting and finger movements. students are not only skilled at counting, but students are able to master a variety of subjects in class. 


\section{Pendahuluan}

Pendidikan karakter saat ini memang menjadi isu utama pendidikan. Selain menjadi bagian dari proses pembentukan akhlak anak bangsa, pendidikan karakter ini pun diharapkan mampu menjadi fondasi utama dalam menyukseskan Indonesia Emas tahun 2025. Dalam UU No. 20 Tahun 2003 Tentang Sistem Pendidikan Nasional Pasal 3 menyebutkan bahwa pendidikan nasional berfungsi mengembangkan kemampuan dan membentuk karakter serta peradaban bangsa yang bermartabat dalam rangka mencerdaskan kehidupan bangsa. Pendidikan nasional bertujuan untuk berkembangnya potensi peserta didik agar menjadi manusia yang beriman dan bertakwa kepada Tuhan Yang Maha Esa, berakhlak mulia, sehat, berilmu, cakap, kreatif, mandiri, dan menjadi warga negara yang demokratis serta bertanggung jawab. Secara umum, persoalan pendidikan karakter bukanlah merupakan masalah baru. Istilah pendidikan karakter, sesungguhnya sudah lahir bersamaan dengan kelahiran istilah pendidikan, sebab pendidikan itu sendiri pada dasarnya adalah untuk mengembangkan karakter baik. Secara khusus, pada sistem pendidikan di negeri ini pernah (bahkan hingga sekarang sebagian masih) terdapat mata pelajaran dengan nama-nama: Budi Pekerti, Aqidah Akhlaq, Pendidikan Agama, Pendidikan Pancasila/P4, Pendidikan Adab, dan lainnya, itu semua tidak lain adalah dalam rangka pendidikan karakter. Pendidikan karakter di sekolah sangat diperlukan, walaupun dasar dari pendidikan karakter adalah di keluarga. Pembentukan karakter siswa di sekolah bertumpu pada kurikulum. Namun, dengan konsep keteladanan sebenarnya telah terjadi pergeseran paradigma untuk mengatasi masalah moral yakni dari berbasis kurikulum resmi menuju kurikulum tersembunyi (hidden curuculum). 4 Pendidikan karakter yang menggunakan pendekatan komprehensif dan holistik yang terintegrasi kedalam setiap aspek kehidupan sekolah, hal tersebut mempengaruhi pendefinisian tentang apa itu kurikulum (Lestari, 2016). Karakter merupakan sifat yang dapat membekali setiap pebelajar menjadi individu yang unggul dan pribadi yang dapat beradaptasi dengan kemajuan teknologi. Kemajuan ini mesti menjadi penunjang dalam pembimbingan mental setiap peserta didik. Kapitalisasi karakter yang dilakukan semenjak anak usia dini turut berpartisipasi menyiapkan generasi bangsa yang berkarakter, mereka adalah calon generasi bangsa yang didambakan berjiwa pemimpin bangsa dan menjadikan negara yang berperadaban, menjunjung tinggi nilai-nilai luhur bangsa dengan akhlak dan etika yang baik serta menjadi generasi yang berilmu pengetahuan tinggi dan menghiasi dirinya dengan iman dan taqwa (Ainiyah, 2013:36).

Kegiatan ekstrakurikuler merupakan wahana dalam mengembangkan bakat dan minat siswa diluar jam pelajaran. Ekstrakurikuler menurut Asmani (2011: 62) adalah kegiatan pendidikan diluar jam mata pelajaran dan pelayan konseling untuk membantu pengembangan peserta didik sesuai dengan kebutuhan, potensi, bakat, dan minat mereka melalui kegiatan yang secara khusus diselenggarakan oleh pendidik dan atau tenaga kependidikan yang berkemampuan dan berwenang di sekolah. Ekstrakurikuler merupakan suatu kegiatan pendidikan yang dilakukan di sekolah yang dilakukan di luar kelas. Dalam Peraturan Menteri Pendidikan dan Kebudayaan Nomor 62 Tahun 2014 mengenai Ekstrakurikuler Pendidikan Dasar dan Menengah bahwa kegiatan ekstrakurikuler adalah kegiatan kurikuler yang dilakukan oleh peserta didik di luar jam belajar kegiatan intrakurikuler dan kegiatan kokurikuler, dibawah bimbingan dan pengawasan satuan pendidikan, bertujuan untuk mengembangkan potensi, bakat, minat, kemampuan, kepribadian, kerjasama, dan kemandirian peserta didik secara optimal untuk mendukung pencapaian tujuan pendidikan. Menurut Lestari (2016) Kegiatan ekstrakurikuler dapat berbentuk individu dan berbentuk kelompok. Kegiatan individu bertujuan mengembangkan baklat peserta didik secara individu atau perorangan di sekolah dan masyrakat. Sementara kegiatan esktrakurikuler secara berkelompok menampung kebutuhan bersama atau berkelompok. Kegiatan ekstra kurikuler merupakan sub sitem dari pendidikan. Kegiatan ekstrakurikuler ini dirasakan wadah yang tepat untuk mengembangkan potensi yang dimiliki oleh peserta didik agar mengembangkan potensi, bakat, minat, kemampuan, kepribadian, kerjasama, dan kemandirian peserta didik secara optimal untuk mendukung pencapaian tujuan pendidikan. Menurut Hambali (2018) Kegiatan ekstrakurikuler merupakan proses menyempurnakan pendidikan pada tingkat kognitif menuju berkesinambungan ke aspek afektif dan psikomotorik sehingga dapat menjebatani masalah pendidikan sekolah dengan pendidikan di keluarga dan tantangan arus deras globalisasi bagi negera-negara berkembang, Indonesia. Secara umum, lembaga pendidikan swasta standar mutunya dari aspek pendidik berorientasi pada ijazah formal, sarana belajar berorientasi dan tradisi belajar berorientasi pada kemampuan menjawab soal UNBK. Pembelajarannya cenderung berjalan secara verbalistik dan berorientasi kepada penguasaan mata pelajaran. Pendidikan difokuskan agar peserta didik memahami informasi yang tersemat dalam materi muatan pelajaran selanjutnya dievaluasi untuk mengetahui seberapa jauh/dalam penguasaan materi yang dicapai oleh pebelajar. Terdapat tiga aspek pembelajaran yaitu aspek kognitif, afektif, dan psikomotorik, dimana dalam konteks evaluasi hasil belajar, maka ketiga domain atau ranah itulah yang harus dijadikan target dalam setiap kegiatan evaluasi hasil belajar. Namun, kebanyakan dalam mengevaluasi hasil belajar 
siswa adalah lebih menitikberatkan dalam ranah kognitif, sedangkan ranah afektif dan psikomotorik kurang dikembangkan. Untuk meningkatkan evaluasi hasil belajar pebelajar dalam ranah afektif dan psikomotorik dapat ditempuh dengan langkah strategis, yaitu melalui kegiatan ekstrakurikuler. Kegiatan ekstrakurikuler diselenggarakan dengan tujuan untuk mengembangkan potensi, bakat, minat, kemampuan, kepribadian, kerjasama dan kemandirian peserta didik secara optimal dalam rangka mendukung pencapaian tujuan pendidikan nasioanal. Tingkat kompetensi semakin tajam, keterampilan berhitung (matematika) sudah menjadi keharusan yang tidak bisa ditawar lagi tetapi kemajuan ini tidak dibarengi dengan kualitas peserta didik yang semakin menurun. Banyak anak didik yang alergi bila harus berhadapan dengan ilmu berhitung dalam jumlah besar, misalnya perkalian dalam bilangan ratusan bahkan ribuan. Kebayakan dari mereka menggunakan alat bantu elektronik seperti kalkulator.

Jarimatika adalah cara berhitung (operasi kali-bagi-tambah-kurang) dengan menggunakan jari tangan. Jarimatika adalah sebuah cara sederhana dan menyenangkan mengajarkan berhitung dasar menggunakan kaidah : dimulai dengan memahamkan secara benar terlebih dahulu tentang konsep bilangan, lambang bilangan dan operasi hitung dasar, kemudian mengajarkan cara berhitung menggunakan jari tangan. Prosesnya diawali, dilakukan dan diakhiri dengan gembira. (Septi Peni Wulandari 2007:2). Pelajaran hitung kerap dianggap membuat bingung oleh siswa dan pada akhinya siswa menjadi tidak tertarik dengan pembelajaran yang dilaksanakan sehingga banyak siswa yang cenderung menghindari pembelajaran berhitung. Pembelajaran yang dihindari siswa biasanya juga tidak dibelajari oleh siswa. Kegiatan ekstrakurikuler jarimatika memberikan pengalaman baru bagi siswa terutama dipembelajaran menghitung sehingga yang biasanya anak-anak menghitung menggunakan metode yang sudah biasa sekarang menggunakn metode baru dengan menggunakan permainan.Anakanak berhitung menggunakan jari terdapat pada kegiatan bernyanyi, berfikir dan menggerakan tangan sehingga membantu siswa untuk lebih mudah mempelajarinya serta anak tidak bosan dan lebih tertarik dengan kegiatan ekstrakurikuler jarimatika.

Muchtar A. Karim dalam jurnal penelitian Pendidikan Guru Sekolah Dasar ,Fakultas Ilmu Pendidikan Universitas Negeri Yogyakarta yang berjudul "Meningkatkan Keterampilan Hitung Penjumlahaan pada Pembelajaran Matematika melalui Permainan Bujur Sangkar Ajaib kelas II SD 1 Pedes Kecamatan Sedayu Kabupaten Bantul". Menyatakan bahwa keterampilam berhitung merupakan keterampilan dasar yang penting dalam pembelajaran matematika.Keterampilan operasi hitung merupakan salah satu tujuan khusus pengajaran matematika di Sekolah Dasar (SD).Keterampilan operasi hitung terdapat berbagai bentuk yaitu penjumlahan, pengurangan, perkalian dan pembagian. Keterampilan berhitung sangat bermanfaat bagi kehidupan sehari-hari membantu mempermudah pemahan konsep-konsep yang dipelajari dan membantu mempermudah penguasaan ilmu pengetahuandan teknologi yang dipelajari dan membantu mempermudah penguasaan ilmu pengetahuan dan teknologi yang diminati .Kegiatan ekstrakurikuler jarimatika membuat siswa lebih cepat dan tepat dalam berhitung yang awalnya siswa memerlukan waktu yang lama dalam berhitung setelah adanya kegiatan ekstrakurikuler jarimatika siswa menjadi terampil dalam berhitung. Kriteria Keterampilan berhitung terdiri dari proses, kecepatan, dan ketepatan.

Berdasarkan observasi awal yang dilakukan oleh peneliti dengan wali kelas IV pada tanggal 3 oktober 2018 di SDN Tlogosari Kulon 01 Semarang bahwa kegiatan ekstrakurikuler jarimatika sudah berlangsung selama 3 tahun. Jarimatika sangat bermanfaat bagi siswa karena merupakan ilmu baru bagi siswa, siswa dapat mengetahui bahwa menghitung tidak hanya seperti yang mereka kenal sebelumnya ada cara yang lebih praktis dan lebih cepat bagi siswa, melalui kegiatan ekstrakurikuler jarimatika siswa yang awalnya memerlukan waktu kurang lebih sepuluh menit dalam berhitung, setelah belajar jarimatika siswa hanya memerlukan waktu kurang lebih 1 menit untuk berhitung. Hal tersebut terjadi karena adanya tahapan- tahapan yang mudah dipahami siswa serta adnya kerjasama antara wali kelas dengan pengajar jarimatika.Jarimatika dapat mengurangi kejenuhan dalam pembelajaran karena ada permainan yang menarik sehingga siswa senang mengikuti kegiatan ekstrakurikuler jarimatika. Cara yang digunakan dalam ekstrakurikuler jarimatika juga sangat menarik meskipun terdapat banyak kelebihan dalam ekstrakurikuler jarimatika, terdapat kendala yang terjadi dalam kegiatan ekstrakurikuler jarimatika yaitu: siswa cendrung kurang tertib dalam mengikuti kegiatan ekstrakurikuler, serta siswa malas untuk menggerakkan jarinya dan lupa rumus jarimatika. Ketika siswa kurang tertib guru yang mengajar ekstrakurikuler dapat menyiasati dengan baik dengan cara bermain dengan bernyanyi dan menggerakan jari sehingga mereka ikut dengan intruksi yang guru berikan.

Perwujudan kegiatan ekstrakurikuler yang melibatkan siswa dalam rangka membangun keterampilan berhitung siswa dalam kegiatan ekstrakurikuler jarimatika dapat membantu siswa agar terampil berhitung dan meningkatkan kualitas yang lebih baik.Sehingga menarik untuk diteliti dalam penelitian yang berjudul "Kegiatan Ekstrakurikuler Jarimatika dalam Membangun Keterampilan Berhitung Siswa Kelas IV Semester II SDN Tlogosari Kulon 01 Semarang”. 


\section{Metode}

Penelitian ini menggunakan pendekatan kualitatif deskriptif. Pendekatan yang dilakukan adalah deskripif kualitatif yang dilakukan dengan menguraikan fakta-fakta atau data-data yang diperoleh dari sumber data.Data-data tersebut selanjutnya dianalisis atau dipaparkan sesuai dengan kegiatan ekstrakurikuler jarimatika di SDN Tlogosari Kulon 01 Semarang.

Adapun tahap penelitian kualitatif Menurut Moleong (2017: 127-151) terdiri dari empat tahap (1) tahap pra lapangan, (2) tahap pekerjaan lapangan, (3) tahap analisis data, (4) tahap penulisan laporan. Prosedur pengumpulan data menurut Prof. DR. Lexy J. Moleong, M.A. (2017:157-162) merupakan langkah yang utama karena tujuan dari penelitian ini adalah mendapatkan data. Prosedur pengumpulan data dalam penelitian ini yaitu berupa wawancara, observasi, angket dan dokumentasi.

Analisis data kualitatif dilakukan secara interaktif dan berlangsung secara terus-menerus sampai tuntas.Sehingga datanya sudah jenuh.Aktivitas dalam analisis data yaitu data reduction (reduksi data), data display (penyajian data), dan conclusion (kesimpulan).

\section{Hasil dan Pembahasan}

Penelitian ini dilaksanakan di SDN Tlogosari Kulon 01 yang terletak di sekolah yaitu SDN Tlogosari Kulon 01 Semarang yang beralamat di perum bumi tlogosari jalan jeruk raya ,tlogosari kulon kecamatan pedurungan kota semarang. SDN Tlogosari Kuon 01 Semarang terdapat bangunan rumah warga, toko dan taman kanak-kanak sehingga alat transportasi yang digunakan siswa hanya sepeda ketika berangkat ke sekolah adapun siswa yang jalan kaki dan diantar oleh orag tua. Lingkungan sekitar SDN Tlogosari Kulon 01 Semarang asri, bersih, rapi, nyaman dan ramah lingkungan .

Jenis penelitian ini digunakan dalam penelitian ini yaitu penelitian kualitatif dengan data yang diperoleh melalui observasi, wawancara, angket dan dokumentasi. Observasi digunakan oleh peneliti untuk mengamati proses pelaksanaan ekstrakurikuler jarimatika di SDN Tlogosari Kulon 01 Semarang. Wawancara digunakan untuk penguatan hasil peneltian berupa fakta-fakta penelitian untuk mengetahui bagaimana ekstrakurikuler jarimatika di SDN Tlogosari Kulon 01 Semarang. Angket digunakan untuk mengukur keterampilan berhitung siswa. Sedangkan dokumentasi digunakan untuk memperoleh data berupa gambar, maupun rekaman suara.

Siswa yang mengikuti kegiatan ekstrakurikuler jarimatika mulai dari kelas IV. Siswa yang mengikuti laki-laki dan perempuan. Jumlah siswa yang mengikuti kegiatan ekstrakurikuler jarimatika 25 siswa yang terdiri dari 11 perempuan dan 14 laki-laki. Berikut hasil presentase angket siswa yang mengikuti kegiatan ekstrakurikuler jarimatika.

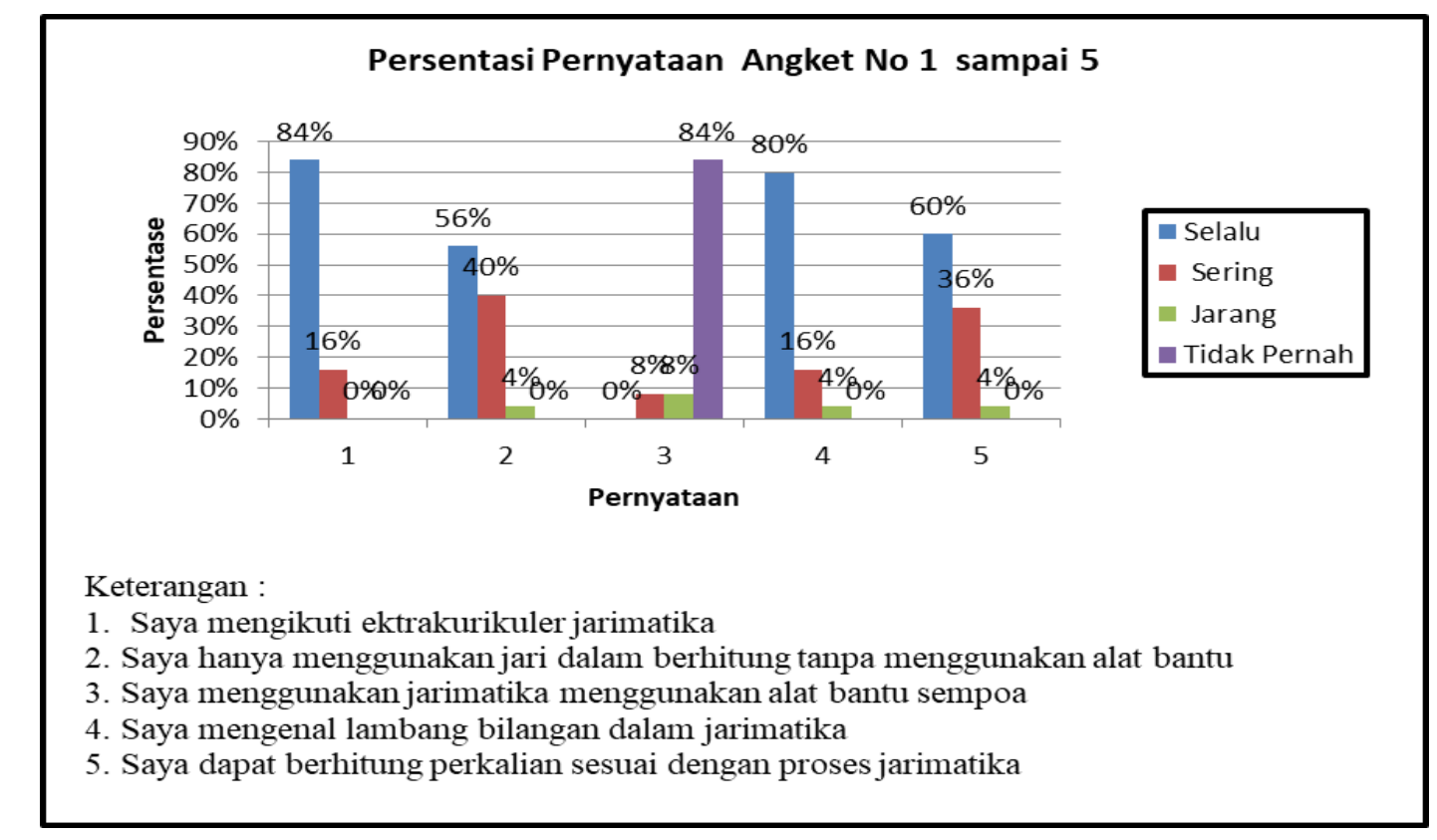

Gambar 1. Presentasi Pernyataan Angket No. 1 Sampai 5 
Berdasarkan Gambar 1 didapatkan bahwa 84\% siswa menyatakan selalu mengikuti ekstrakurikuler jarimatika, 56\% siswa menyatakan sering menggunakan jari dalam berhitung tanpa mengunakan alat bantu. 84\% siswa menyatakan tidak pernah mnggunakan alat bantu sempoa, 80\% siswa menyatakan selalu mengenal lambang bilangan jarimatika, 60\% siswa menyatakan selalu berhitung perkalian sesuai dengan proses jarimatika.

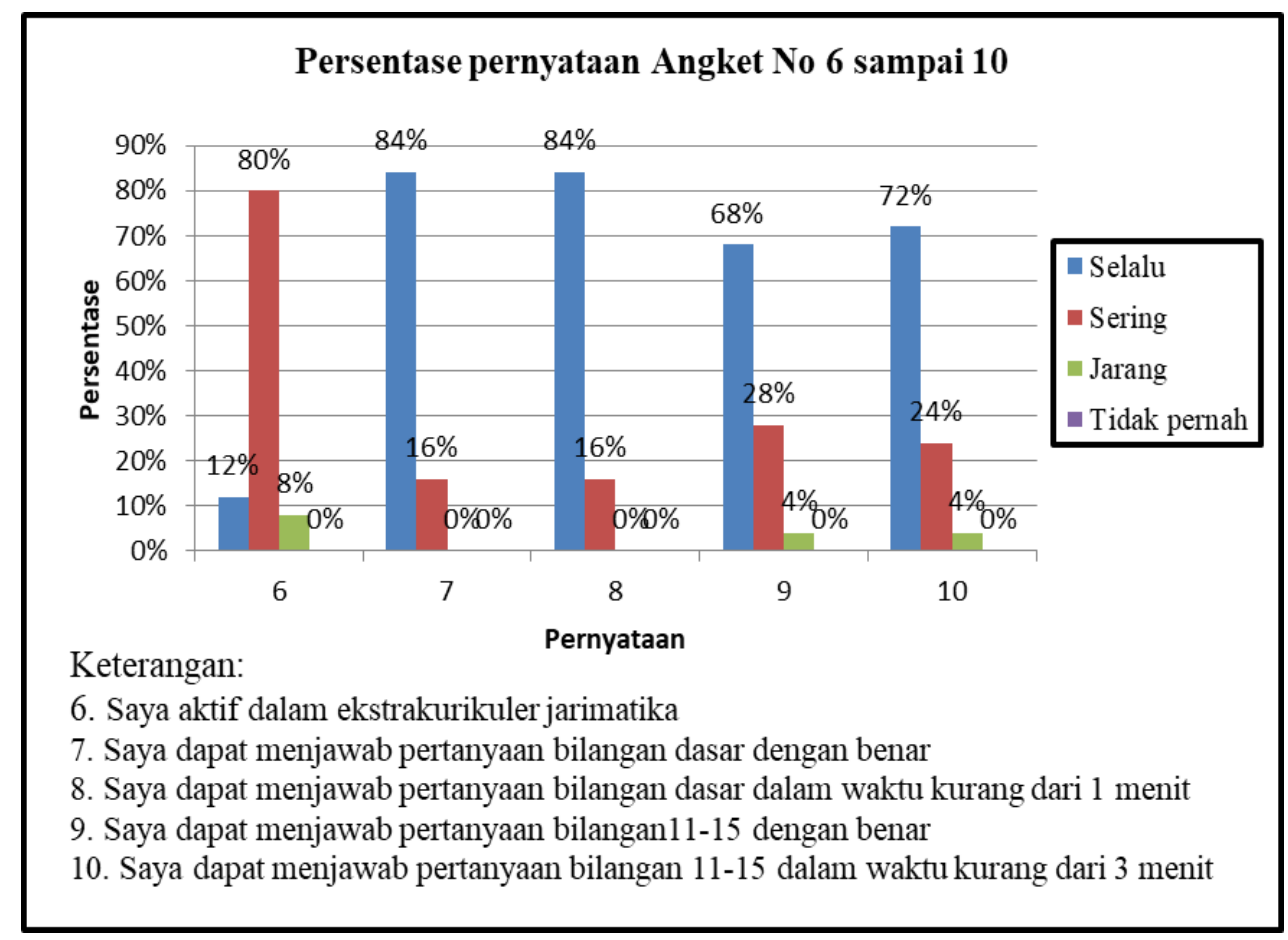

Gambar 2. Presentasi Pernyataan Angket No. 6 Sampai 10

Berdasarkan Gambar 2 didapatkan bahwa 80\% siswa menyatakan sering aktif dalam kegiatan ekstrakurikuler jarimatika, 84\% siswa menyatakan selalu dapat menjawab pertanyaan bilangan dasar dengan benar, 84\% menyatakan selalu menjawab pernyataan bilangan dasar dalam waktu kurang dari 1 menit, 68\% siswa menyatakan selalu dapat menjawab pernyataan bilangan 11-15 dengan benar, dan 72 $\%$ siswa menyatakan selalu menjawab pertanyaan bilangan 11-15 dalam waktu kurang dari 3 menit.

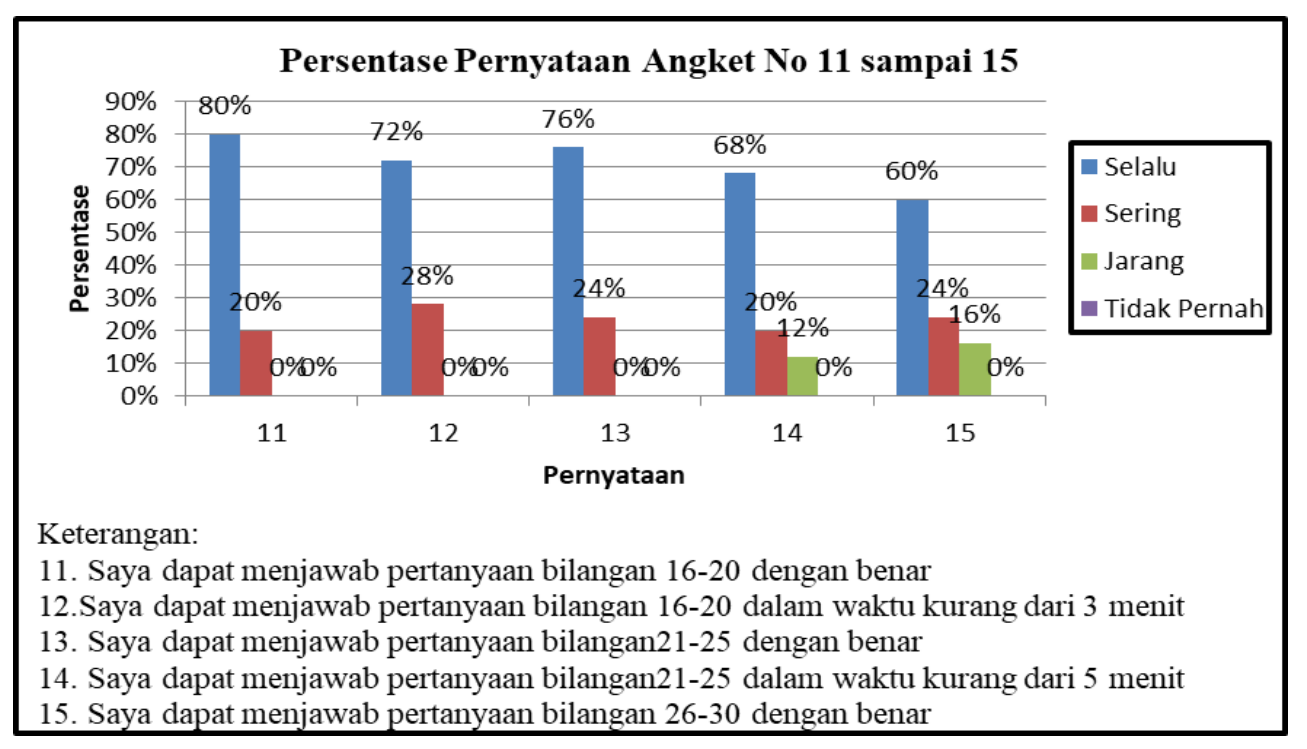

Gambar 3. Presentasi Pernyataan Angket No. 11 Sampai 15 
Berdasarkan Gambar 3 didapatkan bahwa 80\% siswa menyatakan selalu menjawab pertanyaan bilangan 16-20 dengan benar, 72\% selalu menjawab pertanyaan bilangan 16-20 dalam waktu kurang dari 3 menit, 76\% siswa menyatakan selalu menjawab pertanyaan bilangan $21-25$, 68\% siswa menyatakan menjawab pertanyaan bilangan 21-25 dalam waktu kurang dari 5 menit, dan $60 \%$ siswa selalu menjawab pertanyaan bilangan 26-30.

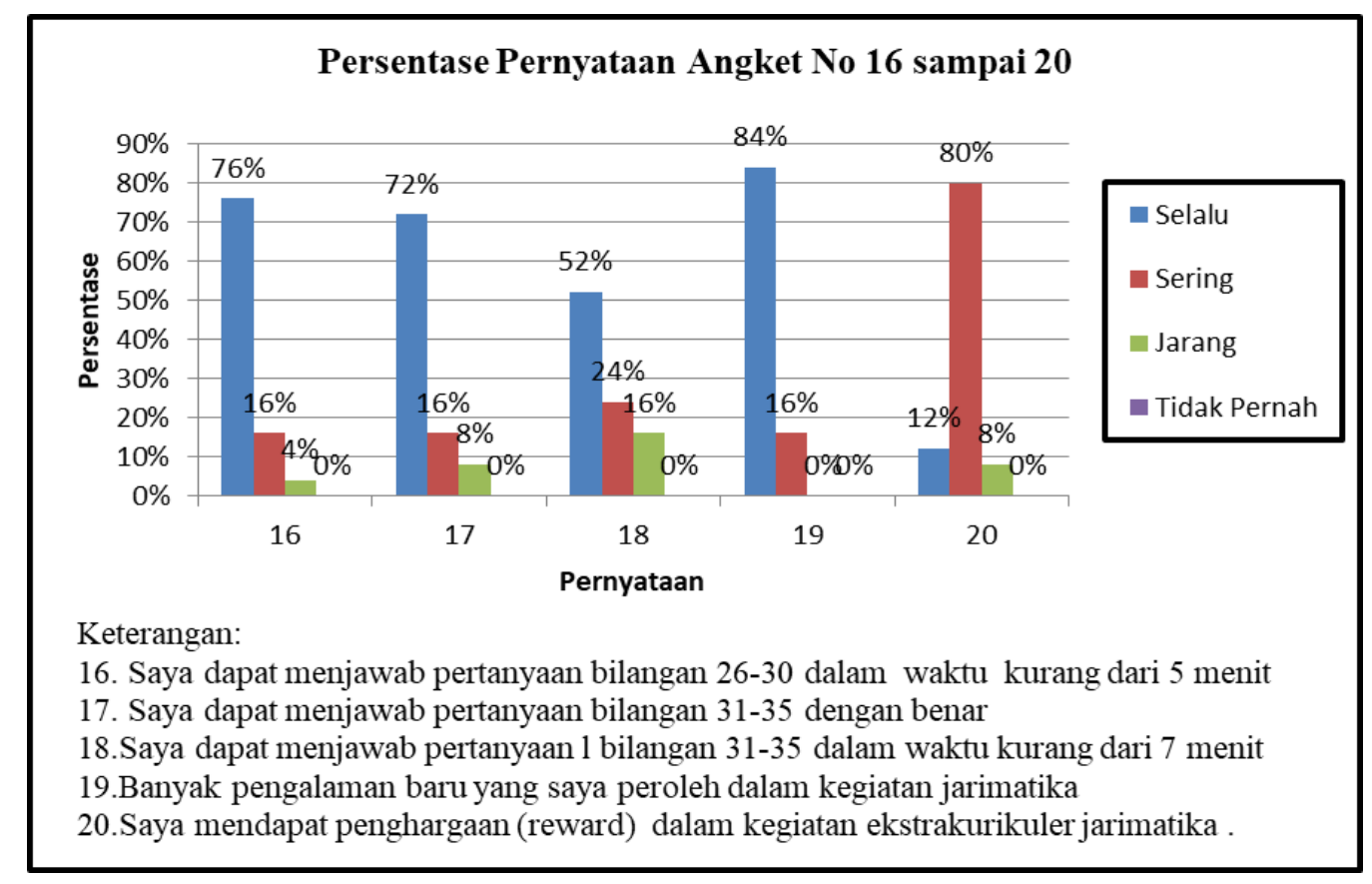

Gambar 4. Presentasi Pernyataan Angket No. 16 Sampai 20

Berdasarkan Gambar 4 didapatkan bahwa $76 \%$ siswa menyatakan selalu menjawab pertanyaan bilangan 26-30 dalam waktu kurang dari 75 menit, 72\% siswa menyatakan selalu menjawab pertanyaan bilangan 31-35 dengan benar. 52\% siswa menyatakan selalu menjawab pertanyaan bilangan 31-35 dalam waktu 7 menit, 84\% siswa menyatakan selalu mendapat banyak pengalaman baru dalam kegiatan ekstrakurikuler jarimatika, dan 80\% siswa menyatakan sering mendapat pengargaan dalam kegiatan ekstrakurikuler jarimatika.

Siswa memiliki minat yang sangat tinggi dengan mengikuti ekstrakurikuler jarimatika. Hal tersebut dapat dilihat dari persentase kehadiran siswa setiap pertemuan kegiatan, selain itu kesungguhan dalam mengikuti kegiatan ekstrakurikuler jarimatika. Hal ini dapat dilihat dari pengamatan peneliti bahwa mereka mengukuti kegiatan ekstrakurikuler dengan senang dan teliti ketika mereka bernyanyi dan berhitung perkalian menggunakan jari sehingga mereka dapat berhitung dengan benar dan tepat sesuai dengan intruksi guru pelatih jarimatika.

Rasa antusias mereka terhadap jarimatika ternyata dipengaruhi oleh guru, keluarga dan masyarakat. Semua keluarga siswa yang mengikuti kegiatan eksstrakurikuler jarimatika sangat mendukung. Dari semua keluarga siswa yang mengikuti ektrakurikuler jarimatika sebagian besar berprofesi sebagai pedagang kelontong dirumah. Sehingga siswa dapat membantu orang tuanya dan berbaur dalam masyarakat.

Berdasarkan pengamatan peneliti bahwa kegiatan ekstraurikuler jarimatika tidak mengganggu jam pembelajaran dikelas karena pembelajaran karena jarimatika dilaksanakan setelah jam pembelajaraan selesai pada jam 14.00 WIB. siswa sangat senang dan antusias dalam mengikuti ekstrakurikuler jarimatika. Melalui kegiatan jarimatika siswa dapat belajar jarimatika sekaligus bernyanyi dan bermain melalui metode unik yang diterapkan di ekstrakurikuler jarimatika.

\section{Simpulan dan Saran}

Berdasarkan hasil penelitian dan pembehasan yang telah diuraikan di bab IV dapat disimpulkan bahwa kegiatan ekstrakurikuler jarimatika dilaksanakan pada hari selasa jam 14.00-15.00. siswa yang mengikuti kegiatan ekstrakurikuler jarimatika sebanyak 25 siswa yang terdiri dari 14 laki-laki dan 11 perempuan. Dari hasil angket terdapat $84 \%$ siswa yang selalu mengikuti ekstrakurikuler jarimatika. 
Siswa sering aktif selama ekstrakurikuler jarimatika berlangsung. Ekstrakurikuler jarimatika membuat siswa senang dan antusias dalam mengikutinya, sehingga membuat siswa mampu menyeimbangkan otak kanan dan otak kiri melalui berhitung cepat dan gerakan jari. sehingga siswa tidak hanya terampil berhitung saja tetapi siswa mampu menguasai berbagai mata pelajaran dikelas.

\section{Daftar Rujukan}

Ainiyah, Nur. (2013). Pembentukan Karakter Melalui Pendidikan Agama Islam. Jurnal Al-Ulum (Jurnal Studi-Studi Islam) IAIN Gorontalo, 13(1).

Arikunto, Suharsimi. 2010. Prosedur Penelitian Suatu Pendekatan Praktik. Jakarta: Rieneka Cipta.

Asmani, J. (2011). Buku Panduan Internalisasi Pendidikan Karakter di Sekolah. Yogyakarta: Diva Pers.

Komandoko, Gamal. 2009. Jari-jari Hitung. Yogykarta: Citra Pustaka.

Hambali, Muh., Eva Yulianti. 2018. Ekstrakurikuler Keagamaan terhadap Pembentukan Karakter Religius Peserta Didik di Kota Majapahit. Jurnal Pedagogik, Vol. 05 No. 02, Hal. 193-208. Tersedia Pada: http://repository.uin-malang.ac.id/3873/1/3873.pdf.

Joko Subagyo,p.2011.Metode Penelitian dalam Teori dan praktik.Jakarta: Rineka Cipta.

Lestari, Prawidya, dan Sukanti. 2016. Membangun Karakter Siswa Melalui Kegiatan Intrakurikuler Ekstrakurikuler, Dan Hidden curriculum (di SD Budi Mulia Dua Pandeansari Yogyakarta). Jurnal Penelitian, Vol. 10, No. 1, Hal. 71-96. Tersedia Pada: http://journal.stainkudus.ac.id/index.php/jurnalPenelitian/article/viewFile/1367/1245.

Lestari, Ria Yuni. 2016. Peran Kegiatan Ekstrakurikuler dalam Mengembangkan Watak Kewarganegaraan Peserta Didik. Untirta Civic Education Journal UCEJ, Vol. 1 No. 2 Hal. 136-152. Tersedia Pada: http://jurnal.untirta.ac.id/index.php/UCEJ/article/view/1887.

Moloeng J Lexy, 2005.Metodologi Penelitian Kualitatif. Bandung: PT Remaja Rosdakarya.

Nur Umi Rahmawati, Dwi. 2014. Implementasi Kegiatan Ekstrakurikuler Jarimatika di Kelas 1 B Min Tempel Ngaglik Sleman Yokyakarta. Skripsi: Universitas Islam Negeri Kalijaga.

Peraturan Menteri Pendidikan dan Kebudayaan Nomor 62 Tahun 2014 Pasal 1 dan 2.

Peraturan Menteri Pendidikan dan Kebudayaan. No 62 tahun 2014 Tentang Kegiatan Ekstrakurikuler Pada Pendidikan Dasar dan Menengah.

Sugiyono. 2015. Metode Penelitian Kuantitatif Kualitatif dan R\&D. Bandung: $\quad$ Alfabeta ,2015. Metode Penelitian Pendidikan Pendekatan Kuantitatif, Kualitatif, dan R\&D. Bandung: Alfabeta.

Sunardar Prasetyono, Dwi dkk, 2009. Pintar jarimatika. Jogjakarta: DIVA Press.

Supriatna, Mamat. 2010. Pendidikan Karakter Melalui Kegiatan Ekstrakurikuler. Universitas Pendidikan Jakarta.

Sri Hardiyanti, M. Maulana, J. Julia.2017.Pengaruh Pendekatan Kontekstual Berbantuan jarimatika terhadap Kemampuan Pemahaman matematis dan Keterampilan Berhitung Siswa pada materi perkalian. Jurnal: Upi Kampus Sumedang.

Tim magic math 100.2010.Magic Math 100. Jakarta: Gramedia.

Yanti Noor, dkk. 2016. Pelaksanaan Kegiatan Ekstrakurikuler dalam Rangka Pengembangan Nilai-nilai Karakter Siswa untuk Menjadi Warga Negara yang Baik di SMA Korpri Banjarmasin.Banjarmasin: Universitas Lambung Mangkurat. 